\title{
ANALISIS TRIWULANAN: Perkembangan Moneter, Perbankan dan Sistem Pembayaran, Triwulan I - 2011
}

\author{
Tim Penulis Laporan Triwulanan, Bank Indonesia
}

Rapat Dewan Gubernur (RDG) Bank Indonesia pada 12 April 2011 memutuskan untuk mempertahankan BI Rate sebesar 6,75\%. Keputusan ini tidak mengubah arah kebijakan moneter Bank Indonesia yang cenderung ketat sebagai upaya untuk pengendalian tekanan inflasi yang masih tinggi, di tengah upaya Pemerintah menurunkan tekanan inflasi dari kelompok volatile foods. Dewan Gubernur memandang bahwa penguatan nilai tukar Rupiah sejauh ini dapat menurunkan tekanan inflasi, khususnya yang berasal dari kenaikan harga komoditi internasional (imported inflation). Selain itu, untuk meminimalkan dampak negatif aliran modal asing jangka pendek terhadap stabilitas moneter dan sistem keuangan, Dewan Gubernur juga memutuskan untuk menggantikan ketentuan one-month holding period terhadap SBI menjadi six-month holding period mulai berlaku 13 Mei 2011. Ke depan, Bank Indonesia menilai masih terbuka ruang penyesuaian level BI Rate untuk meredam tekanan inflasi lebih lanjut. Bank Indonesia meyakini bahwa penerapan bauran kebijakan moneter dan makroprudensial tersebut, serta didukung pula dengan penguatan koordinasi kebijakan Pemerintah, akan mampu untuk menjaga stabilitas makro dan membawa inflasi pada sasaran yang ditetapkan, yaitu 5\% $\pm 1 \%$ pada tahun 2011 dan 4,5\% 1 1\% pada tahun 2012.

Dewan Gubernur memandang bahwa pemulihan ekonomi global ke depan lebih baik sebagaimana terlihat dari penyesuaian ke atas proyeksi pertumbuhan ekonomi global oleh berbagai lembaga internasional. Optimisme global yang membaik ini akan berdampak pada volume perdagangan dunia yang juga meningkat. Hal tersebut akan berpengaruh positif terhadap permintaan terhadap produk ekspor sehingga turut mendorong pertumbuhan ekonomi domestik. Namun, proses pemulihan ekonomi global ini masih menghadapi risiko ketidakpastian terkait krisis utang yang melanda sejumlah negara di Eropa dan potensi gangguan proses produksi pascagempa di Jepang. Selain itu, kenaikan harga minyak dan komoditi pangan dunia diperkirakan masih berlanjut sehingga memberikan tekanan inflasi di banyak negara maju dan emerging economies, termasuk Indonesia.

Di sisi domestik, Dewan Gubernur berpandangan bahwa pertumbuhan ekonomi Indonesia diprakirakan meningkat sebesar 6,0-6,5\% pada tahun 2011 dan 6,1-6,6\% pada tahun 2012 . 
Pertumbuhan ekonomi tersebut ditopang oleh sumber pertumbuhan yang semakin berimbang seiring dengan kinerja investasi yang terus meningkat dan kinerja ekspor yang masih tetap solid. Pada triwulan II-2011, pertumbuhan ekonomi diprakirakan tumbuh cukup tinggi yaitu sebesar 6,4\%. Peran investasi untuk penambahan kapasitas perekonomian, terutama melalui PMA, diperkirakan akan meningkat sejalan dengan masih kuatnya permintaan, baik dari domestik maupun eksternal, serta membaiknya sovereign credit rating. Secara sektoral, seluruh sektor ekonomi diprakirakan akan tumbuh tinggi, dengan pertumbuhan tertinggi pada sektor transportasi \& komunikasi, sektor perdagangan, hotel \& restoran, dan sektor bangunan.

Kinerja Neraca Pembayaran Indonesia diperkirakan masih akan mencatat surplus yang cukup besar pada 2011. Surplus tersebut berasal baik dari transaksi berjalan maupun transaksi modal dan finansial. Ekspor diprakirakan masih akan tumbuh cukup tinggi. Aliran masuk modal asing dalam bentuk portofolio diperkirakan masih akan tetap besar, sedangkan investasi asing langsung (PMA) diperkirakan meningkat. Dengan perkembangan sampai dengan akhir Maret 2011, cadangan devisa tercatat sebesar 105,7 miliar dolar AS atau setara dengan 6,3 bulan impor dan pembayaran utang luar negeri.

Tren penguatan nilai tukar Rupiah terus berlanjut pada Maret 2011. Di samping sejalan dengan kinerja NPI yang mencatat surplus yang besar dan positifnya persepsi investor asing terhadap kuatnya fundamental ekonomi Indonesia, penguatan Rupiah juga sebagai bagian dari respons kebijakan Bank Indonesia untuk pengendalian tekanan inflasi, khususnya yang berasal dari kenaikan harga komoditi internasional (imported inflation). Hingga akhir bulan Maret 2011 nilai tukar Rupiah menguat sebesar 3,47\% (ptp) menjadi Rp8.708 per dolar AS. Apresiasi Rupiah sejauh ini belum mempengaruhi daya saing Indonesia dari sisi nilai tukar, antara lain tercermin dari kinerja ekspor nonmigas Indonesia yang terus menunjukkan peningkatan yang relatif tinggi.

Di sisi harga, meskipun inflasi sudah menunjukkan kecenderungan menurun, risiko tekanan inflasi ke depan diperkirakan masih cukup tinggi. Inflasi IHK pada bulan Maret 2011 mencapai 6,65\% (yoy) atau deflasi 0,32\% (mtm) seiring dengan koreksi inflasi bahan pangan. Meskipun masih relatif tinggi, tekanan inflasi dari kelompok volatile foods menunjukkan kecenderungan yang menurun sejalan dengan langkah-langkah Pemerintah untuk memperkuat pangan nasional. Sementara inflasi administered prices cukup moderat terkait dengan minimalnya kebijakan penyesuaian harga oleh Pemerintah. Namun, inflasi inti menunjukkan tren meningkat, tercatat sebesar 4,45\% (yoy) atau 0,25\% (mtm) pada Maret 2011, sebagai dampak rambatan dari tingginya harga pangan dan meningkatnya ekspektasi inflasi. Ke depan, risiko tekanan inflasi diperkirakan masih cukup tinggi, dipengaruhi oleh meningkatnya harga komoditi internasional, kuatnya permintaan domestik, dan tingginya ekspektasi inflasi. Bank 
Indonesia akan terus mewaspadai risiko tekanan inflasi tersebut dan memperkuat bauran kebijakan moneter dan makroprudensial untuk mengendalikan inflasi ke sasaran yang telah ditetapkan.

Stabilitas sistem keuangan tetap terjaga yang disertai terus membaiknya fungsi intermediasi perbankan dan likuiditas perbankan yang terkendali. Industri perbankan cukup stabil ditandai oleh terjaganya kondisi permodalan dan likuiditas sebagaimana tercermin pada tingginya rasio kecukupan modal (CAR/Capital Adequacy Ratio) pada level 18\% dan terjaganya rasio kredit bermasalah (NPLNon Performing Loan) gross di bawah 5\%. Intermediasi perbankan juga semakin membaik tercermin dari pertumbuhan kredit yang terus meningkat, yakni pada Maret 2011 mencapai 25,1\% (yoy), ditopang oleh pertumbuhan pada seluruh jenis kredit termasuk kredit kepada UMKM. 
372 Buletin Ekonomi Moneter dan Perbankan, April 2011

halaman ini sengaja dikosongkan 